\title{
Mine oplevelser i det sønderjyske arbejde ved århundredskiftet*)
}

\author{
Af Knud Fabricius.
}

For nogle ár siden hørte man hyppigt det udtryk: "Held dem, der blev studenter i den rette tid «. Hvad er meningen med disse ord? Formodentlig, at man måtte prise de studenter lykkelige, der kom til verden - altså den akademiske verden - på et tidspunkt, hvor det ândelige klima var gunstigt for en harmonisk udvikling af deres personlige evner og egenskaber. Det er næppe forsvarligt at tro, at ordene alene skulde sigte til, at studenten blev student på en tid, hvor studieforholdene var økonomisk set lette og behagelige; ikke en gang, om man tillagde, at studierne skulde stå $\mathrm{i}$ flor og bæres frem af betydelige og energiske lærere. Nej, tanken må være, at kulturens standpunkt skulde ligge så højt, at den, der begyndte et akademisk liv, havde gode udsigter til herigennem at blive et fuldt udviklet og mangesidigt interesseret menneske. Til disse interesser hørte forst og fremmest samfølelse med det folk, man tilhørte, og trang til at dele dets skæbne.

Om tiden nu er "den retle" for sludenten, er det svært for en gammel eks-student at afgøre. Men jeg tror, at jeg har været så heldig at høre til dem, der blev student $\supset i$ den rette tid «. Det var i de sidste ti år af forrige århundrede, en tid, der ganske vist var mindre bevæget, end 1870erne og 1880erne, men også mindre stormfuld; en tid, da de politiske lidenskaber var ved at falde til ro, og det åndsliv, der havde begyndt at udfolde sig $i$ de foregående ti-år, nu stod i sin fulde blomstring. Det var Georg Brandes', Holger Drachmanus, Gustav Esmanns og Peter Nansens, men også Johs. Jørgensens, Henrik Pontoppidans og Jakob Knudsens tid, og i videnskaben græssede konservative får og radikale ulve side om side. I studenterverdenen havde Studenter-

*) Foredrag holdt i studenterforeningen „Heimdal“ den 10. december 1960. 
samfundet arbejdet sig op til en jævnbyrdig stilling med den gamle Studenterforening, og som et ydre symbol herpå havde det taget sit eget hus i besiddelse på Frueplads, ironisk nok vis a vis Fruekirke, så at det $i$ en sang ved indvielsen hed om Jeppe Aakjær:

"Til Vor Frue vil han smile smørret, hver gang Paullis Røst hans Øre naar«.

Som et lille træk til tidens ireniske præg kan jeg anføre, at jeg først var medlem af Studenterforeningen i nogle år, derefter af Samfundet.

Da modsætningerne $i$ livsanskuelse og politik således var ved i nogen grad at udjævnes, var det også naturligt, at interessen for den sønderjyske sag, der hidtil havde været et privilegium for Studenterforeningen, nu også dukkede op i Samfundet, vel nok mere af liberale grunde, som respekt for folkenes selvbestemmelsesret, end af patriotisme og af tro på § 5's levedygtighed, som havde til huse i Studenterforeningen.

Det var navnlig de yngre inden for Samfundet, mænd som H. V. Clausen, Joh. Ottosen, Aage Friis og P. Munch, som havde blik herfor, mens jeg $\mathrm{i}$ denne kreds har hort den ytring om Hørup, at han nok helst så landet lige op til Kongeåen snarest muligt fortysket for at få denne anstødssten $\mathrm{i}$ forholdet til vor mægtige og truende nabo fjernet. Men i denne yngre kreds var der en oprigtig interesse for Sønderjylland, sålangt dansk sindelag og sprog rådede. Clausen skrev en ypperlig rejsefører over landet og undersøgte hver gårds og hvert hus' nationale forhold; Ottosen lever endnu i sin sang »Det haver så nyligen regnet «, og det var derfor naturligt, at der dannedes en sønderjysk forening inden for Studentersamfundet $\gg 4$ S (d. v. s. Studenter-Samfundets Sønderjyske Samfund), svarende til "To Løver» inden for Foreningen. Den fik til formand professor Har. Høffding, en højtanset forsker, der havde en sjælden indflydelse på studenter af alle politiske retninger.

Høffding var ikke en ven af de store og stærke ord, der den gang endnu ofte lød ved sønderjyske møder i Danmark. Han foretrak afgjort handling til gavn for sønderjyderne, og da han fandt en lignende stemning hos studenter i Studentersamfundet, 
indbød han (sammen med papirhandler J. Chr. Petersen i "Hvælvingen" ved Nikolaj kirke) til dannelsen af en sammenslutning indenfor $4 \mathrm{~S}$., der skulde soge kontakt med de unge nordslesvigere, der opholdt sig i Danmark på højskoler og efterskoler. For at gøre dette ophold endnu mere frugtbart for dem, indbød man dem en søndag $i$ måneden til at komme ind til København, hvor man viste dem rundt $i$ hovedstadens museer og samlinger, skaffede dem gratis adgang til Det $\mathrm{kgl}$. Teaters eftermiddagsforestillinger og endte dagen med en fælles spisning på en restaurant med påfølgende punschesold, hvor en bekendt kulturpersonlighed indledte med et kort foredrag af nationalt indhold. Det økonomiske grundlag for virksomheden påtog Høffding og Petersen sig at skaffe. Denne sammenslutning fik på forslag af Høffding navnet Vidar" efter den tavse as, der uden et ord ofrede sin ene hånd i Fenrisulvens gab. "Heimdal o er den søsterforening til sVidar", der omtrent samtidig dannedes indenfor "To Løver".

"Vidar"s første formand blev min ven, stud. mag. Anker Jensen (senere lektor i Haderslev), og jeg selv var fra forste færd med $i$ »Vidar «, der havde omkr. et dusin medlemmer, alle studenter. Nogle af disse var sønderjyder, som $H$. T. Physant (senere skoleinspektør i Kobenhavn) og Marie Hjorth fra Langetved (senere læge i Ringsted), men de fleste var kongerigske, som Viggo Holten-Bechtolsheim (senere højesteretssagfører), Albrechtsen (lektor i Randers), Herman Christensen (opfinder inden for fysiken), Niels Bjerrum (prof. i kemi og fmd. for Carlsberglaboratoriets bestyrelse) o. fl. Adskillige af os medbragte kærligheden til Sønderjylland fra hjemmet; Holten var således søn af den sidste danske soldat, der i 1864 gik tilbage over Ejderen, og personlig var jeg vokset op $i$ en præstegård, hvor mindet om de sønderjyske krige og håbet om § 5's gennemførelse var levende realiteter, (selv om man hellere talte om treårskrigen end om 1864), og hvor "Flensborg Avis og dets folgeblad >Nordslesvigsk Søndagsblad a læstes ivrigt af den opvoksende dreng.

Enhver idealistisk ungdom vil onske at omsætte sin idealisme i handling. Man syntes den gang, at der sforegik " så lidt, både i verden i almindelighed, og i Danmark i særdeleshed. Den store verdensfred syntes at være nået; $i$ mere end et kvart århundrede havde man ikke haft krig mellem stormagterne. Men en ungdom 
onsker ikke statiske, den foretrakker dynamiske forhold. Naturligvis ikke sådan ment, at den i en fredsperiode langes efter krig. Men den vil gerne være med til at arbejde aktivt for en ideel sag. Og den eneste ideelle sag, som Danmark havde at byde på $i$ forholdet til omverdenen, var den sønderjyske sag. Der var fremgang i den; fra valg til valg steg det danske stemmetal ved valgene til den tyske rigsdag og den preussiske landdag, og den nordslesvigske ungdom viste et gå-på-mod og et lyssyn, der stod i stærk modsætning til de første ti-år efter 1864. Det var ikke de ringeste af den danske akademiske ungdom, som ønskede at være med i deres kamp, selv om det ikke kunde blive som egentlige kombattanter.

Vi tog altså fat på vore søndagsmøder i vinterhalvåret, og det gik over forventning. Der kom gennemgående en snes unge mænd med toget ind til byen fra de sjællandske høj- og efterskoler, og nogle af os viste dem rundt på museerne og gik med dem i Det kgl. Teater, der stillede de fornodne fribilletter til vor rådighed. Men dagens hojdepunkt var aftensmåltidet, der $i$ reglen fandt sted i Søpavillonen. Her mødte hele skaren af sønderjyder og rigsdanske sammen, og vi havde altid det held at få xet stort navn til at holde den indledende tale. Det var mænd som Hoffding, Troels Lund, Erik Skram, så vidt jeg husker endogså Georg Brandes, og deres ord blev huskede af tilharerne $i$ årevis derefter. Det eneste, man kunde beklage, var, at deres ord ikke kom en langt større tilhørerkreds til gode. Efter talen var ordet frit, og -Vidar «s medlemmer fik lejlighed til at vise deres talegaver. Men hvad der navnlig overraskede, var, hvor vægtige og velformede vore gæsters indlæg var. De var åbenbart skolede $i$ deres hjemstavns danske forsamlingssale fra en tidlig alder. Så kom opbruddets time, thi toget lod ikke vente på sig. Vort medlem Physant, der jo var landsmand i snævreste forstand med gæsterne, havde da altid den vane at få det sidste ord, ved med sit muntre lune at forme de sidste afskedsord, så at aftenen endte $i$ den hedste stemning.

Men der var også de lejligheder, hvor den alvorlige stemning var den fremherskende. I slutningen af 90erne begyndte fra tysk side den såkaldte "Køllerperiode", hvor man tog alle midler $i$ hrug for at kue det danske sindelag. Harmen herover var så al- 
mindelig, at ikke blot samfundslag, der hidtil havde vist ringe interesse for den sønderjyske sag, som det danske socialdemokrati, vedtog protestadresser, men de preussiske metoder vakte endog en pinlig opmærksomhed $i$ de store landes presse. Blandt Kollers germaniseringsmetoder var også den, at han truede de forældre i Sønderjylland, der havde sønner på danske høj- og efterskoler, med, at hvis de ikke kaldte dem hjem, vilde man fra tysk side svare med at udvise de danske statsborgere i Nordslesvig med kort varsel. Efterretningen om dette skridt kom til Danmark netop på en søndag, da vi havde møde med unge sønderjyder i »Vidar". Stemningen ved aftensbordet var, som rimeligt, ganske trykket, men inden mødet var til ende, var det blevet klart for alle tilstedeværende, at sønderjyderne ikke vilde bøje sig for de tyske trusler og agtede at blive på skolerne i Danmark. Det var for sVidar"s medlemmer, som om de havde oplevet et pust af de store begivenheder. Forøvrigt vovede den tyske regering, da det kom til stykket, ikke at gøre sine trusler til virkelighed.

Når vinteren var til ende, og sønderjyderne på normal vis rejste hjem, havde "Vidariterne" deres private samvær, der heller ikke let glemmes. Jeg husker således en sommeraften (1898?), da jeg, der nu var foreningens formand efter Anker Jensen, stod med en halv snes medlemmer foruden disses kvindelige gæster på Holte station efter et animeret møde i Sølbrød kro. Det sidste tog til København var gået, og vi syntes at stå over for den eneste mulighed, at måtte bruge apostlenes heste på den 2 mile lange vej til hovedstaden. Så måtte alle medlemmer trade afsides fra vore damer og tømme deres portemonnæer i min hat; og se, det lykkedes at rejse de $10-20 \mathrm{kr}$., som det kostede at leje en charabanc. Under munterhed foretoges så hjemturen ad Kongevejen, men solen stod op, da vi over Dronning Louises bro trillede ind $\mathbf{i}$ København.

"Vidar " havde i det hele en evne til at skabe godt kammeratskab blandt sine medlemmer, ja, her dannedes venskaber, der holdt gennem hele livet. Hvor stor en rolle spillede ikke her Viggo Holten-Bechtolsheim ved sin muntre sarkasme, et af de intelligenteste og samtidig ædleste mennesker, som jeg har kendt. Eller vor initiativrige og varmtfølende formand, Anker Jensen. Kosle- 
lige var hans bestandige dyster med vort eneste kvindelige medlem, Marie Hjorth, der aldrig syntes, at der hlev udreltet nok. Hun var som en oldtidens amazone, dog uden at færdes på hesteryg, og hun var tillige en dyb og grublende natur, der bl. a. var optaget af - som hun sagde - med visse mellemrum at revidere sine anskuelser på de forskellige områder, når hun mærkede, at de ikke længer stod i logisk samklang med hverandre. At det var studenter fra alle studiefag: jurister, medicinere, filologer, historikere og naturvidenskabsmænd, som mødtes i "Vidar", gav også livet her en farve og fylde, som næppe vilde have været til stede, hvis det havde været studenter af samme fag.

Nogle af "Vidariterne" fik desuden lejlighed til at mødes med de sønderjyske gæster i deres hjem i Nordslesvig. H. V. Clausen, der kendte hvert hjem dernede, havde truffet den aftale med en større kreds af gårdmænd, at han skulde få danske studenter til at rejse til Sønderjylland i sommerferien, hvor de så skulde være gæster på nordslesvigske gårde. Selv kom jeg til at benytte dette i sommeren 1898, da jeg på cykle kom over Kongeåen ved Skodborg, og der blev modlaget af Marie Hjorth, som førte mig til sit hjem. Det var forste gang. jeg besøgte det tabte land, og i de folgende dage gennemstrejfede jeg det $i$ hele dets længde, ja Holsten med lige til Lübeck. Mange træk fra dette besøg står endnu levende for mig, og jeg tror endnu at kunne fole omheden i mine lægge, da en ung landmand ved aftenstid pacede mig fra Gram til Bovlund, bakke op, bakke ned i et tempo, som man ikke kendte fra Sjælland. Af de mangfoldige indtryk på rejsen skal jeg kun omtale to. Det ene fra en restaurant på torvet i Haderslev en markedslardag, hvor jeg var sammen med en hel skare unge bønder fra omegnen. Stemningen var fortrøstningsfuld og munter, og jeg husker bl. a., at de forhørte hinanden om, hvem der var abonnent på den nyudkomne "Danmarks Riges Historie", og at de, som ikke kunde klare sig under forhøret, blev godt drillede af de andre. Kunde man have tænkt sig en lignende samtale blandt bønder i kongeriget? Den anden scene foregik nogle dage senere i Ábenrå. Der holdtes da synodemøde i teatret; synoden var den valgte forsamling af præster og lægmænd til behandling af kirkens og skolens spørgsmål, og det problem, som skulde behandles, og som samtidig draftedes i alle fire nordslesvigske am- 
ler, var det stadig tilbagevendende danske forslag om indforelse i folkeskolen af 2 ugentlige timers danskundervisning for at give eleverne mulighed for at få noget udbytte af timerne $i$ religion. Jeg var blevet snuglet ind af journalisterne fra de dansksindede blade og sad blandt dem i en balkonloge, hvorfra jeg havde et udmærket overblik over salen. Der så man regeringens repræsentant, landråd v. Uslar, (landråd = amtmand), provst Reuter, storbonden Jep Hinrichsen (en gammel slesvig-holstener) og et halvhundrede prester og bønder i broget blanding. Forhandlingerne begyndte, og det var interessant at se de forskellige typer træde frem: Den »schneidige " landråd, der lidligere havde været preussisk lojtnant; den salvelsesfulde provst, den brutale slesvigholstener, samt flere tyskere, der i de voldsomste ord bekæmpede forslaget. I modsæining til dem de danske honder, der alle roligt og sagligt sagde deres mening. Det var virkelig modsætningen mellem hammer og ambolt, og om ens rent menneskelige sympatier kunde der ikke være tvivl. Men der fandtes også en tredje gruppe, flertallet af præsterne. De var tyske, men de lagde ikke skjul på, at danskundervisningen for dem var blevet en samvittighedssag p. g. a. de sørgelige forhold $i$ skolen og ved konfirmationsforberedelsen. Som deres vigtigste talsmand stod præsten Wulff i Varnæs, der hævdede, at forslaget drejede sig om at afhjælpe "Kirkens nød . Ved denne gruppe præsters støtte lykkedes det de dansksindede repræsentanter at gennemføre deres forslag, om end med knebent flertal, ligesom det samtidigt også vedtoges $\mathrm{i}$ de tre andre nordslesvigske synoder. Ganske vist faldt det derefter med et brag på den slesvig-holstenske generalsynode i Rendsborg, hvor hele provinsen stemte under eet. For mig var modet i Ảbenrå næsten uhyggeligt ved at vise det officersmassige standshovmod, den provstelige sleskhed og den hadske brutalitet hos standsfællerne, de tysksindede bonder, som var vore landsmænds værste modstandere.

Arene gik. Det hold studenter, der havde stiftet *Vidar ", fuldførte sine universitetsstudier og forlod for størstedelen København. Men nye årgange af akademikere fyldte deres pladser i "Vidar , der viste sin levedygtighed lige til genforeningens tid. Den første verdenskrig skulde ganske vist forst gennemstrides og gennemlides af sønderjyderne, men så kom også den slund, 
da alle kunde se, at den nationale kamp ikke havde varet forgæves. Selv det lille strå, som "Vidar" har slæbt til stakken, viste sig at have båret frugt.

De første \&Vidariter var nu mend med koner og børn, og nogle af os var så heldige at kunne overvaere genforeningen på sonderjysk grund. Jeg skal ikke her tale om velkendte emner, som festen i Kongeskansen på Dybbøl 10. juli 1920, hvor jeg (med min familie) horte statsminister Niels Neergaard love de udelukkede sydslesvigere, at "de ikke skal blive glemt", amtmand Schack afgive nordslesvigernes troskabslofte til kongen, og hvor kong Christian kyssede det gamle dannebrogsflag, der blev overrakt ham af hans nye undersâtter. Men det er de små, selvoplevede træk, der tit fæster sig stærkest i hukommelsen.

Allerede før Dybbølmødet fortalte Martin Hammerich, der var kommet til Sønderborg tidligere, mig, at han en dag, da han cyklede på en bivej ude på Als, havde hørt sang inde bag hegnet, og da han bøjede grenene til side, fik han øje på ell ung pige, der sad på marken og malkede, mens hun sang:

- Længe nok har jeg Bondepige varet, siddet paa Tærskel og spundet paa min Ten

Nu vil jeg glad sidde, hvor jeg sad, forrest vil jeg gaa i de dansendes Rad.*

Vi andre, der kom efter ham, kunde også opleve lignende træk af stemningen: den åbne favn i Sønderjylland, hvormed vi blev modtagne. Ganske vist også sådanne træk, som kaldte på vemod, som fra sydslesvigernes mode med kongen i Kruså. Om kong Christian sagde man forøvrigt, at da han på vejen til dette mode kom til Rinkenæs, hvor udsigten over Flensborg fjord åbner sig, spurgte han blot: "Kan man se Lyksborg herfra? " Det var hans slægts stammeslot, der ikke var kommet med inden for den nye grænse. Samme dag kom jeg med min familie cyklende i skarp vestenvind op ad bakken til Rørkær, en landsby nogle få $\mathrm{km}$ uden for Tønder. Ud af et af husene kom der da løbende en lille skare børn, der bar et dannebrogsflag mellem sig. Med skingrende barnestemmer ribte de til os:

"Vi æ blewn dansk!"

Kunde vi have ydermere vidnesbyrd behov? 